\title{
1. When arrows from the jungle aim at the heart of modern intellectual property rights
}

\subsection{INTRODUCTION}

Issues pertaining to the ownership, management and transfer of natural resources have historically been of central importance in international law. Concerns about environmental degradation have enriched the discussion on the ownership and management of valuable natural resources, introducing legal obligations related to their preservation and sustainable use. Genetic resources are no exception to this, and in the past decades, international negotiations, international conventions and a vivid debate have all attempted to find a way to combine the conservation and sustainable use of such resources while at the same time securing the fair and equitable sharing of the benefits arising from their use. This really is an era of green developmentalism, in which nature is subject to extensive commodification, on the basis of which both environmental and conservationist concerns and the sharing of benefits are addressed.

The advent of biotechnology has contributed in this direction, opening up space for new, revolutionary uses of genetic resources and constituting the basis for the development of commercial products mainly in the areas of agriculture and pharmaceuticals. Intellectual property rights (IPRs) and the exclusive rights they provide to the results of R\&D in the field, aside from increasing the commercial potentials of these products, have also brought to the surface another new parameter in the already established natural resources discussion, namely that of the value of know-how regarding their applications. In the field of genetic resources, such know-how is very often embodied in what is called traditional knowledge (TK). TK-related applications provide valuable leads to researchers in the agricultural and pharmaceutical fields and thus become a necessary intangible asset accompanying tangible genetic resources for the purposes of this book, named 'traditional knowledge on genetic resources' (TKGR). The net effect of these recent developments is an increasing interest in IPRs and access to TKGR. 
Today, biodiversity constitutes one of the major sources of inspiration, as well as a major source of raw material, for a number of different industries, such as agriculture, biotechnology, food, cosmetics and pharmaceuticals. Growing consumer interest in 'green products' is reorienting scientific interest towards the search for novel natural substances. TKGRbased biotechnological research presents considerable advantages; for example, success ratios in trials concerning the search for valuable genetic resources increase from 1 in 10,000 samples to 1 in 2 . In fact, the use of TKGR could increase efficiency in screening plants for medicinal properties by more than 400 per cent. Obviously, both the higher success ratios obtained by employing TKGR in preliminary research and shorter development times for new products reduce costs, leading to higher profitability. ${ }^{1}$

The challenges posed to the IPR system with regard to the protection of TKGR concern well-known questions, namely how (if at all) to protect subpatentable innovation and when and under which circumstances an emerging valuable subject matter justifies the introduction of a new entitlement, either under one of the established IPRs or under the scope of sui generis rights. These questions are of course more than familiar to the IPR world, and the protection of TKGR would in fact be a typical IPR question were it not for that fact it has become a symbol of North/South inequality.

Since the discussion takes place in the framework of IPRs, it needs to address whether the TKGR is in fact a new subject matter worthy of protection, or whether its protection entails a further enclosure of the public domain. It is furthermore debatable whether an exclusive right (already existing or sui generis) is a necessary measure for TKGR, or whether other means of protection, such as measures against unfair competition or liability rules, are equally appropriate.

The transfer of TKGR from the South to the North is not a new practice. The value of TKGR trade has been recognised since ancient times, marking international relations and constituting the background of wars and political decisions. These practices flourished even more during colonial times. Economic colonialism was in some cases based on the transfer and exploitation of TKGR. During colonial times, scientists, breeders and botanists from the colonising world collected and transferred useful and rare plant genetic resources to their home countries. At the time, plant genetic resources were considered 'common resources'.

1 Prakash, G., Science and the Imagination of Modern India, Princeton: Princeton University Press (1999), pp. 201-27. 
With a few exceptions of restricted access, such as in the notable cases of rubber, quinoa and cacao, ${ }^{2}$ genetic resources were shared by and accessible to all. In the twentieth century, the regulatory structures changed dramatically, initiating a process of gradual commodification of genetic resources that has lasted for decades. ${ }^{3}$ As observed above, technological innovation laid the ground for the development of industries, commercially exploiting genetic resources and associated know-how.

The emerging interest in TKGR access and exploitation has brought to the surface a number of unfortunate market failures originating in the special characteristics of TKGR trade and in the weaknesses of the legal framework. ${ }^{4}$ It is developing countries, with expanding populations and limited scientific and technological development, that contain valuable biodiversity. One of the main concerns of the developing world has been that scientists from technology-intensive countries have accessed genetic resources that were later adapted into commercially viable valuable forms, protected by patents or other IPRs and eventually sold back to developing countries, often at prohibitive prices. ${ }^{5}$ In this respect, TKGR holders tend to overestimate the contribution of their resources and of

2 Monson, J., 'From Commerce to Colonization: A History of the Rubber Trade in the Kilombero Valley of Tanzania, 1890-1914', History, Vol 21 (1993), pp. 113-30.

3 During the latter part of the twentieth century, the discussion on commodification of an endless list of subject matter came to be of major interest. With market freedom on the one hand and the risk of dehumanisation on the other, the evaluation of liberatory economic rhetoric became more and more relevant. Obviously, with commodification theories applied to the market in babies for childless couples, in body parts and in human beings, it was only logical to expect they would reach TKGR too. See Radin, M., Sunder, M., 'The Subject and Object of Commodification', Stanford Law School Public Law and Legal Theory Working Paper Series, Research Paper No 97 (2004).

4 A long list of patents granted on what was previously considered traditional medicine or agriculture is presented in McGown, J., 'Out of Africa: Mysteries of Access and Benefit Sharing', Edmonds Institute in Cooperation with African Centre for Biosafety (2006).

5 Tolan, S., 'Against the Grain: Multinational Corporations Peddling Patented Seed and Chemical Pesticides are Poised to Revolutionize India's Ancient Agricultural System. But at What Cost?', LA Times, 10 July 1994, p. 18. See also Wolfgang, L., 'Patents on Native Technology Challenged', Science, Vol 15 (1995), p. 1506. Another interesting article is Roht-Arriaza, N., 'Of Seeds and Shamans: The Appropriation of the Scientific and Technical Knowledge of Indigenous and Local Communities', Mich J Int L, Vol 17 (1996), pp. 936-7. 
their traditional knowledge in the development of the end products. ${ }^{6}$ On the other hand, they usually have very minor experience with IPRs, if any, and only limited possibilities to offer a realistic prognosis of their future commercial value. The general mistrust of the system just described is strengthened by the fact that IPRs protect the end products originating in the developed world while providing limited or no protection for the initial contribution, no matter how crucial it is - as in the case of TKGR. Developing countries very often express concern that the current intellectual property (IP) system does not provide any protection against acts of misappropriation of TKGR-related innovation, excluding it indirectly from the scope of protectable subject matter. ${ }^{7}$

Developed nations focus more on the ability to maintain their right to unrestricted access to genetic resources while defending the current structure of the IPRs system and the protection this affords their technological achievements. An argument often employed to defend this position is that technology transfer is dependent on the existence of strong IPRs and enforcement mechanisms. For the developed world, technological applications that contribute the necessary modifications of a substance in order to turn it into a commercial product are recognised as the core value of the innovation, while the value of genetic resources and TK is considered to be limited simply to that of a raw material. ${ }^{8}$

The increasing commercial interest in TKGR and the belief that it is possible to protect it (or its derivatives) by means of the IPR system

6 See for instance Marden, E., 'The Neem Tree Patent: International Conflict over the Commodification of Life', BC Int L \& Comp L Rev, Vol 22 (1999), pp. 279-95.

7 On the challenges faced by the modern IPRs, see Levin, M., 'Intellectual Property Rights in Transition: Legal Structures and Concepts in Adaptation to Technological Challenges. Towards an Intellectual Property System for the 21st Century. A Nordic-European Research Programme' in Wahlgren, P. (ed), Intellectual Property, Scandinavian Studies in Law Vol 42, Stockholm: Stockholm Institute for Scandinavian Law (2002), p. $83 \mathrm{ff}$.

8 On the importance of TKGR for pharmaceutical research see Schmitt, E.K., Moore, C.M., Krastel, P., Petersen, F., 'Natural Products as Catalysts for Innovation: A Pharmaceutical Industry Perspective', Current Opinion in Chemical Biology, Vol 15 (2011), pp. 1-8. See also Patwarhan B., Annant Mashelkar, R., 'Traditional Medicine-Inspired Approaches to Drug Discovery: Can Ayurveda Show the Way Forward?' Drug Discovery Today, Vol 14 (August 2009), pp. 804-9, referring to the Tanga project in Tanzania under which 4000 AIDS patients were treated with herbs prescribed by traditional healers. Very interesting results were reported with regard to the reduction of opportunistic diseases accompanying HIV infection. 
raises the question of whether it is possible for traditional knowledge to be commodified, and thus become valuable to a broader public, without posing a threat to the social structures that sustain it and the livelihoods of indigenous peoples that depend on it. One of the fundamental assumptions behind the strategies to protect TKGR is that indigenous peoples represent a coherent and authentic voice, while the protection of their traditional knowledge is projected as their sole and maybe final chance to fight Westernisation. Little attention is paid to the changing conditions of the everyday lives of indigenous communities or to their respective diverging approaches with regard to bioprospecting and TKGR protection.

The protection of TKGR has gradually become one of the major challenges of twenty-first-century international law, ${ }^{9}$ as well as of the international IPRs system. TKGR is one of those few subject matters whose protection lies at the crossroads of a broad spectrum of diverging rights and institutional frameworks, raising a wide range of issues, from land rights to human rights, plant genetic resources regulation, environmental regulations and IP protection. ${ }^{10}$

The complexity of the subject matter and the multiple interconnecting actors do not facilitate clear-cut solutions to the TKGR market failures. At the same time, several international organisations have included TKGR protection in their respective negotiations and agreements. TKGR is thus subject to a complex regime that is of importance to multiple individual legal institutions, with overlapping rules. As a result, the international legal framework regulating the legal status of TKGR provides for a number of potential layers of protection, consisting mainly of: ${ }^{11}$

- The 1961 International Union for the Protection of New Varieties of Plants (UPOV), concerning breeders' rights over new plant varieties that they breed intentionally. Plant breeders' rights are a new form of IP protection for plant varieties. ${ }^{12}$

9 Dutfield, G., Intellectual Property Rights, Trade and Biodiversity, London: Earthscan (2000), p. 62 ff.

10 For an elaboration of the process of bioprospecting and where it leads to, see Posey, D., Dutfield, G., Beyond Intellectual Property: Toward Traditional Resource Rights and Indigenous Peoples and Local Communities, Ottawa: IDRC (1996), pp. 5-64.

11 Listed in chronological order.

12 International Convention for the Protection of New Varieties of Plants, Paris, 2 December 1961, as Revised at Geneva on 10 November 1972, 23 October 1978 and 19 March 1991 (UPOV Doc 221(E), 1996). 
- The UN Food and Agriculture Organization (FAO), which has elaborated two key international agreements: (1) the 1983 International Undertaking on Plant Genetic Resources; and (2) the 2001 International Treaty concerning the regulation of access to plant genetic resources. ${ }^{13}$

- The Convention on Biological Diversity (CBD), regarding the conservation of biodiversity, the sustainable use of its components and the fair and equitable sharing of the benefits arising therefrom. The CBD also makes reference to indigenous communities' rights. ${ }^{14}$

- The World Trade Organization (WTO) Agreement on Trade-Related Aspects of Intellectual Property Rights (TRIPS), setting minimum international standards for the protection of IPR. ${ }^{15}$

The background, and in some cases a side effect, of the complex TKGR regime is the internationalisation of TKGR access and the legal status of TKGR. ${ }^{16}$ Despite the plethora of potentially relevant legal institutions in the field, to this day the legal regime related to the protection of TKGR remains unclear and difficult to apply. ${ }^{17}$ The international instruments

13 FAO (1987), Extract of the twenty-second session of the FAO Conference, Rome, 5-23 November 1983. Resolution 8/83 - International Undertaking on Plant Genetic Resources and Annex. CPGR/87/ Inf 3 FAO, Rome. International Treaty on Plant Genetic Resources for Food and Agriculture through FAO Resolution 3/2001.

14 The CBD was signed at the Earth Summit in Rio de Janeiro, Brazil, in 1992 and entered into force on 29 December 1993. It is the first global agreement to cover all aspects of biological diversity: the conservation of biological diversity, the sustainable use of its components and the fair and equitable sharing of benefits arising from the use of genetic resources. For the text of the Convention see http://www.cbd.int.

15 Agreement on Trade-Related Aspects of IPR Art 1(1), 15 April 1994, Marrakesh Agreement Establishing the World Trade Organization, Annex 1C, 33, ILM 1197, 1198 (1994) - Results of the Uruguay Round, Vol 2133 LLM 1197, 1201 (hereinafter the TRIPS Agreement).

16 See Rosendal, K., 'Impacts of Overlapping International Regimes: The Case of Biodiversity', Global Governance, Vol 7 (2001), pp. 95-117, discussing the phenomenon of overlapping rules and institutional regimes in this particular case.

17 The limitations of the current IPR system with regard to the protection of traditional knowledge, as well as the side effects of the lack of a clear-cut legal entitlement and potential remedies for this, have been debated and negotiated in various forums, such as UNESCO, WHO, WIPO, UNEP, UNCTAD, FAO, CGIAR, World Bank, and COP, but also in a number of NGOs. The decentralised 
mentioned above create the preconditions and lay the ground for the introduction of a new legal entitlement, but do not go as far as to actually establish one. ${ }^{18}$

Currently there is no specific legal entitlement protecting TKGR on the international level. National legislative and regulatory initiatives of relevance have attempted to embody the general principles provided for under the international regime and address their interaction with the current IP system, but have not demonstrated satisfactory results.

Post-CBD reports and negotiations in the field have focused either on the practical aspects of a sui generis right for the protection of TKGR or on the specific adjustments necessary in order to accommodate this 'new' subject matter under the realm of traditional IPR. Such approaches are certainly fully legitimate if the focus is the drafting of a ready to use legal tool to accommodate TKGR trade in the short run. Whether this is the natural, correct or most efficient approach may be disputed, however.

The lack of a concrete entitlement is an undeniable complication in a world where the exploitation of TKGR - bioprospecting - is an established practice. However, the lack of conceptual clarity complicates both the application of the vague legal system and the development of a viable long-term solution for the protection of TKGR. In fact, the lack of conceptual clarity concerns not only terminology related to TKGR, such as 'traditional knowledge' and 'genetic resources', but also terminology of central importance to the general legal system, such as that of property, common resources and open access.

This book investigates the need of a legal entitlement covering TKGR $a b$ initio. While the dominant part of the relevant literature considers the natural place of TKGR protection to ipso facto lie under the realm of private property rights, ${ }^{19}$ this book tests a number of variations of possible protection frameworks.

One of the starting points of the approach chosen relates to the fact that this is not the first time we have searched for an appropriate legal entitlement for natural resources and associated know-how. In fact, some

approach to the negotiations concerning the protection of TKGR presents obvious weaknesses in terms of coordination and coherence.

18 Both the CBD and the ITPGRFA refer to the principle of protection of traditional knowledge and to fair and equitable sharing of the benefits arising from the use of genetic resources, but neither introduce a legal entitlement covering traditional knowledge.

19 See also Reichman, J., 'Of Green Tulips and Legal Kudzu: Repackaging Right in Subpatentable Innovation', Vanderbilt L Rev, Vol 53 (2000), pp. 174398. 
of the particularities of TKGR were also present in the evolution of land rights, ${ }^{20}$ as well as in the case of deep-sea resources. ${ }^{21}$ It is thus possible to draw parallels from past experiences of resource allocation when considering the protection of TKGR.

Despite the fact that the elaboration of an appropriate form of entitlement for TKGR might give us the impression of deja vu regarding the old traditional concerns of resource allocation, it presents certain particularities that may not be overlooked. The management of TKGR via the grant of a legal entitlement suggests two objectives: access and conservation. The TKGR regulation should thus 'reward' the holders of TKGR and promote further conservation, while on the other hand facilitating access to TKGR of interest and allowing its inclusion in sequential innovations. ${ }^{22}$

Both the CBD and the FAO instruments have put in place a general legal framework that aims to regulate the transfer and trade of TKGR. The FAO framework proposes a communitarian regime covering a predetermined range of plant genetic resources, while the CBD opts for an expressive commodification based on a clear statecentric approach. By means of its Access and Benefit Sharing (ABS) provisions, the CBD creates a set of economic incentives for the conservation of biological diversity. ${ }^{23}$

Regional and national implementation initiatives have attempted to interpret and elaborate on the provisions of the CBD, introducing layers of new potential legal entitlements and a list of different groups of rightholders, ranging from ministries to governmental authorities and indigenous peoples' representatives. National legislation provides for detailed schemes of contractual structures (bioprospecting agreements), designed to regulate access to TKGR. These agreements are very often developed under licensing agreement models that would normally presuppose the existence of some form of legal entitlement on the traded

20 Regulated by human rights norms. See for instance UN Human Rights Committee, Ominayak and the Lubicon Lake Band v. Canada (1990), Annual Report of the Human Rights Committee, UN Doc A 45/40, Bd. II AP A (1990).

21 See for instance the 'common heritage of mankind' principle, to be discussed later in this book.

22 In the case of TKGR, the protection framework seems to be burdened with another task: environmental protection in the form of conservation and sustainable use of biodiversity.

23 Siebenhuner, B., Dedeurwaerdere, T., Brousseau, E., 'Introduction and Overview to the Special Issue on Biodiversity Conservation, Access and Benefit Sharing and Traditional Knowledge', Ecological Economics, Vol 53 (2005), pp. 439-44. 
subject matter. What is, however, miraculously lacking both in the text of the CBD and in the subsequent implementation initiatives is a specification of the nature and structure of the traded entitlements. The only right expressly provided for on the international level is that of state sovereignty over national genetic resources. Although the recognition of national sovereignty is a notable development and bears an impact on the status and thus the trade of TKGR, it certainly cannot offer a satisfactory legal framework.

IPRs have become the natural resort for such an analysis, not just because the forthcoming entitlement has been placed under their scope, but also because they have a major impact on TKGR trade since they grant exclusive rights on end products and processes encompassing such subject matter. Moreover, major actors in the TKGR market, on the users' side, are dependent upon IPRs for their continued activities. ${ }^{24}$ This twofold IP approach - on the one hand, the possibility to patent end products and the impact of this on the realisation of 'fair and equitable sharing of the benefits' arising out of the TKGR trade; on the other, the possibility to protect the starting material (TKGR) with sui generis IPRs - actually creates new pressures for the current IP system and poses fundamental challenges to its further development and future role. ${ }^{25}$

The overarching goal of this book is to present and evaluate alternative forms of entitlements for the protection of TKGR by testing the following:

- The scope and content of the constraints and requirements placed on the elaboration of a TKGR entitlement on the basis of the binding international agreements.

- The national and regional initiatives in the elaboration of such an entitlement, the choices made, the outcome and the extent to which available flexibilities were taken into account.

- The possibility to proceed to a systematisation of the principles and objectives important in the process of elaboration of a new entitlement, in this case on TKGR.

24 Well-known examples are obviously the pharmaceutical industry and the biotech industry. See also Maskus, K.E. 'Intellectual Property and the Transfer of Green Technologies: An Essay on Economic Perspectives', WIPO Journal, Vol 1 (2009), pp. 133-7.

25 See in this respect Oguamanam, C., 'Localizing Intellectual Property in the Globalization Epoch: The Integration of Indigenous Knowledge', paper presented at the fourth Annual Doctoral Students Conference of the Association of Pacific Rim Universities, Mexico City, Mexico (24-29 August 2003). 
To what extent would the present objectives and principles assist in the process, and what outcome would they have for TKGR protection?

\subsection{THE EVALUATION FRAMEWORK}

Evaluation of the already tested alternative forms of protection for TKGR, as well as the proposal of an 'ideal' legal entitlement for the specific subject matter, should be based on certain prespecified objectives. Efficiency seems like a natural starting point, since one of the main purposes of this entitlement is the frictionless operation of the TKGR market.

On the other hand, taking into consideration the objectives that should be attained by means of the upcoming entitlement, the special characteristics of TKGR as a subject matter and the interests of its potential rightholders, a pure efficiency-based analysis would provide a restricted perspective. As a result, this book chooses to proceed to a discussion and evaluation of alternative forms of protection on the basis of a combination of the Coasean model on economic efficiency and a theory of equity and justice. Efficiency and equity are terms that have been employed in a number of different theories and models. For the purposes of this book, the use of 'equity and justice' is based on Rawls' theory of fairness as justice. ${ }^{26}$

In his article 'The Problem of Social Cost', 27 Ronald Coase made a groundbreaking contribution to the law and economics literature. According to the Coase Theorem, where market transactions are costless, rearrangements of rights will always take place if these lead to an increase in the value of production. In Coase's world of zero transaction costs, parties negotiate and reach agreements that maximise the total output of the transaction, being both efficient and wealth maximising.

26 Rawls, J., The Law of the Peoples, Cambridge, MA: Harvard University Press (2001); Swygert, M., Yanes, K.E., 'A Unified Theory of Justice: The Integration of Fairness into Efficiency', Wash L Rev, Vol 73 (1998), pp. 249-324. In their article, Swygert and Yanes propose a combination of the Coase Theorem and of the Rawlsian model on fairness. Although this model has been criticised in literature, and while the methodological framework of this study is not solely restricted to the said model, Swygert and Yanes' contribution will serve as a starting point upon which to build a combination model of efficiency and equity: see in particular pp. 304-24 of their article.

27 Coase, R.H., 'The Problem of Social Cost', J Law Econ, Vol 3 (1960), pp. 1-44. 
Thus governmental intervention should in fact 'copy' the outcome of the negotiation in a marketplace with no transaction costs.

Rawls, on the other hand, conceptualised the principle of social justice and the effects this should have on the evolution of the legal system. In his book $A$ Theory of Justice, ${ }^{28}$ Rawls envisages a situation where participants in a would-be society are gathered under a 'veil of ignorance'. ${ }^{29}$ While they know everything about human history, conditions and nature, they know nothing about their own situation. These members of the society are called to develop the principles of governance on the basis of their mutual interest. The fact that they are bargaining while unaware of whom/what they represent makes them intuitively empathetic towards the needs and interests of others, because those 'others' could easily be themselves.

With regard to international justice, Rawls provides for a somewhat nuanced methodological approach in the introduction of a fairness perspective in the Law of Peoples. ${ }^{30}$ The Law of Peoples is a political perception of right and justice applied in international relations. To arrive at his elaboration of the Law of Peoples, Rawls once again employs the principles of the 'original position' and the veil of ignorance, this time applicable to peoples and not individuals.

Both the Coase Theorem and Rawls' theory build upon a hypothetical model of consensus resulting from bargaining. Coase bases his theoretical model on a costless bargaining scheme. Rawls' consensus model, meanwhile, relates to society's constitutional framework and the recognition of human or fundamental rights, as well as principles of encouraging liberty and at the same time addressing inequalities. In order to ensure that personal interest does not prevail, individuals participating in the Rawlsian bargaining model are covered by a veil of ignorance with regard to their economic and social situations.

A major difference between the two models is the importance of rational empathy in the Rawlsian model, and its total absence in the Coase Theorem. ${ }^{31}$ Rawls' veil of ignorance presupposes that individuals will take into consideration the importance and need of a 'security net for

\footnotetext{
28 Rawls, J., A Theory of Justice, Oxford: Clarendon Press (1972).

29 Rawls (1972).

30 Rawls, J., 'The Law of Peoples', Critical Inquiry, Vol 20 (1993), pp. 3668.

31 Adelstein, R., 'Equity and Efficiency in Markets for Ideas', Conn J Int L, Vol 17 (2001-2), pp. 1-14.
} 
all' ${ }^{32}$ The rational individuals in Rawls' original position would opt for the most efficient use of available resources in order to create the highest expected outcome. Risk aversion will thus have a balancing effect. Individuals would be willing to accept a lower expected possible outcome in order to ensure any positive outcome. ${ }^{33}$ Rawls' concept of 'constructive empathy' is more than an emotion - rather, it is a rational choice. ${ }^{34}$ Thus, constructive empathy is not a result of pity and compassion but rather a strategic choice, and in this regard the two models are in fact complementary to each other. ${ }^{35}$

\subsubsection{Efficiency: The Coasean Approach}

\subsubsection{The Coase Theorem}

The appropriate institutional framework for the allocation of entitlements has been one of the most debated subjects in the field of law and economics. The path-breaking contribution of Ronald Coase, in 'The Problem of Social Cost', 36 and the subsequent massive literature stemming from both proponents and opponents to his Theorem, has been and still is one of the major intellectual platforms in the field. The Coase Theorem provides that in a world of zero transaction costs, rights will be rearranged in view of increasing production value. Originally, the Coase Theorem was formulated to address the issue of negative externalities, but during the past five decades it has been applied to a number of distinct areas of law, from the market for hepatitis-free blood to declarations of war to IPRs. ${ }^{37}$

32 Dworkin, R., 'Rawls and the Law', Fordham L Rev, Vol 72 (2003-4), pp. 1387-92.

33 For an analysis risk of aversion see Bosch-Domenech, A., Silvestre, J., 'Does Risk Aversion or Attraction Depend on Income?', Economics Letters, Vol 65 (1999), pp. 265-73.

34 Merritt, G., 'Justice as Fairness: A Commentary on Rawls' New Theory of Justice', Vand L Rev, Vol 26 (1973), pp. 665-86.

35 Individuals are thus willing to give up part of the wealth surplus in order to guarantee that their actual welfare will not fall under a specific level.

36 Coase (1960), pp. 1-44.

37 For a 'critique' of the application of law and economics to IPRs see Rahmatian, A., 'A Fundamental Critique of the Law-and-Economics Analysis of Intellectual Property Rights' in Dinwoodie, G. (ed), Methods and Perspectives in Intellectual Property, Cheltenham: Edward Elgar (2013), pp. 71-114. For clear support, see Lands, W.M., Posner, R.A., 'An Economic Analysis of Copyright Law', in Posner, E.A. (ed), Law and Economics, Aldershot: Ashgate (2000), pp. 325-63, where law and economics is applied to copyright law. 
Coase's contribution was initially expressed as an opposition to the classic (and, at the time, well established) Pigouvian approach to the necessity of governmental intervention. ${ }^{38}$ Coase claimed that an initial assignment of entitlements is irrelevant to overall welfare. According to Coase, all involved agents will seek to conclude mutually advantageous bargains. In other words, Coase assumes that the parties are rational - an assumption that also constitutes one of the Theorem's weaknesses, since rationality is a subjective concept. ${ }^{39}$

The vagueness in the Theorem's formulation has allowed for a number of interpretations and reformulations. According to Stigler, the Theorem established that under perfect competition, private and social costs will be equal;40 Cooter, meanwhile, considered that resource allocation is efficient regardless of the structure of liability law, provided that bargaining is frictionless. ${ }^{41}$ Farell reformulated Coase's hypothesis, saying that since nothing obstructs efficient bargaining, people will negotiate until they reach Pareto efficiency. ${ }^{42}$ Notwithstanding the subsequent reformulations and interpretations of both followers and opponents, all seem to agree on a number of common fundamental assumptions. Hoffman and Spitzer summarised the major common assumptions as follows: ${ }^{43}$ two agents in the bargaining; perfect information of the agents; competitive markets; zero transaction costs; costless litigation; profit-maximising producers; no wealth effects; pursuit of mutually advantageous bargaining.

A fundamental assumption of the Theorem - and the major source of its flexibilities and, at the same time, its alleged weaknesses - is zero transaction costs. Coase did not provide for any further definition or

38 The 'conflict' between the Coase Theorem and the Pigouvian approach has been challenged. See Simpson, B., 'Coase v. Pigou Reexamined', J Legal Stud, Vol 25 (1996), pp. 53-97. Coase presented a view that was in direct conflict with Pigouvian legal tradition. He claimed that in the absence of transaction costs, those who are responsible and those who suffer from negative externalities will negotiate an efficient allocation of resources, independent of the initial assignment of rights among them.

39 Elsten, J., 'More than Enough', Univ Chicago Law Rev, Vol 64 (1997), pp. 749-61.

40 Stigler, J., The Theory of Price, New York: The Maximilian Co. (1966), p. 113.

41 Cooter, R., 'The Cost of Coase', J Legal Stud, Vol 11 (1982), pp. 1-33.

42 Farrell, J., 'Information and the Coase Theorem', J Econ Persp, Vol 1 (1987), pp. 113-29.

43 Hoffman, E., Spitzer, M., 'The Coase Theorem: Some Experimental Tests', J Law Econ, Vol 21 (1982), pp. 73-98. 
clarification of this term; this has been a strong focus of both followers and opponents.

Transaction costs have been defined as the costs of bringing bargainers together, of maintaining and revising the agreement and of the capital required to affect the agreement. ${ }^{44}$ They include costs spent on getting a large number of people together to bargain and costs of excluding freeloaders. ${ }^{45}$ They are also identified as the costs that occur when trading partners attempt to identify and contact one another (identification costs), when contracts are negotiated (negotiation costs) and when the terms of the contracts are verified and enforced (enforcement costs). ${ }^{46}$ Dahlman reiterates that there are three classes of transaction costs: those of search and information; those of bargaining and deciding; and finally those of policing and enforcement. These are in fact all due to the parties' lack of information. ${ }^{47}$ According to Demsetz, the level of transaction costs varies from one case to another. Product standardisation is a transaction cost-reducing factor since buyers need not examine the goods in person, and feel comfortable with allowing others to buy and sell for them. ${ }^{48}$ Naturally, a high level of uncertainty and infrequent transactions are both factors that could lead to increased transaction costs. ${ }^{49}$ The level of transaction costs can also vary depending on the nature of the transaction in question, uncertainty, rare exchanges and the level to which investments are transaction-specific. ${ }^{50}$

In some cases, transaction costs are so low that it is more desirable to allow the market to solve the deficiencies. According to Daly, ${ }^{51}$ this happens in cases where a limited number of parties are bargaining and

44 Toumanoff, P., 'A Positive Analysis of Market Failure', Kyklos, Vol 37 (1984), pp. 529-38.

45 Toumanoff (1984), pp. 529-38.

46 Mishan, E.J., 'The Postwar Literature on Externalities: An Interpretative Essay', J Econ Lit, Vol 9 (1971), pp. 1-16.

47 Dahlman, C.J., 'The Problem of Externality', J Law Econ, Vol 22 (1979), pp. $141-8$.

48 Demsetz looked into the transaction costs in the New York Stock Exchange and concluded that the securities that were most traded entailed fewer transaction costs: Demsetz, H., 'The Cost of Transacting', Quarterly J Econ, Vol 82 (1968), pp. 33-50.

49 Williamson, O., 'Transaction-Cost Economics: The Governance of Contractual Relations', J Law Econ, Vol 22 (1979), pp. 233-61.

50 Williamson (1979), pp. 233-61.

51 Daly, G., 'The Coase Theorem, Assumption, Application', Economic Inquiry, Vol 12 (1974), pp. 203-13. 
where competition prevails in the market. Farell adds that marketoriginated solutions are preferable where there is private information, the government would be unable to make use of the information in question, there is a lack of artificial barriers that could block voluntary private contracts and the negotiating parties are limited in number and easily identified. ${ }^{52}$

\subsubsection{Implications of the Theorem}

Coase claimed that in a market of zero transaction costs, the initial allocation of entitlements would not be important with regard to economic efficiency since the entitlement would in any case end up with the party valuing it the most. Rational parties will always bargain in order to achieve Pareto-optimal allocation of resources. ${ }^{53}$ Obviously, Coase did not consider his world of zero transaction costs and perfect competition to be a reflection of the real world and real markets. He was rather making an $e$ contrario statement: in the real world, the initial allocation of entitlements is important and has an effect on the allocation of resources, since transaction costs are not negligible.

The Theorem sheds new light on the role of private negotiations in the rule-making process. When comparing different policy solutions, one should take into account deficiencies in the system that can be resolved by means of private bargaining. According to Farell, when evaluating an institution, one needs to examine the outcomes of the institution per se before investigating which defects can be remedied by negotiation. ${ }^{54}$

Consequently, when introducing a new legal entitlement it is of importance to work with the certainty and predictability of the legal rule as well as with its substance. Transaction costs might obviously concern one party more than the other, since the party suffering less is the one that can more easily trade around an inefficient rule. In the well-known and often employed example of pollution, the polluter is to be held liable since he or she is the one who holds the private information on the level of pollution. ${ }^{55}$ Another policy alternative might be to assign the entitlement to the party that values the right most. Obviously, this is the

\footnotetext{
52 Farell (1987), pp. 113-29.

53 Pareto optimality is named after the Italian sociologist and economist Vilfredo Pareto (1848-1923) and is a situation in which economic resources and output are allocated in such a way that any change to make an individual better off would entail that someone else would be worse off.

54 Farell (1987), pp. 113-29.

55 Randall, A., 'Market Solutions to Externality Problems, Theory and Practice', Am J Agric Econ, Vol 54 (1972), pp. 175-8.
} 
solution that would be reached by the parties should transaction costs be zero. When the entitlement is assigned to the party most desiring the right, then there is no bargaining incentive in the market.

The Coase Theorem has been subject to harsh critique and a series of attempts to illustrate its shortcomings and weaknesses over the years. It has, however, managed to prevail. Calabresi, one of the scholars who initially criticised it, reconsidered his views and stated that the conclusions Coase reaches remain the same in the short as well as the long term. ${ }^{56}$ Demsetz became a proponent of the Theorem in $1972,{ }^{57}$ presenting his application of the Coasean model according to which the long-term effects of a change in the assignment of property rights do not nullify the conclusions reached by Coase.

The Coase Theorem had a significant impact on the seminal dichotomy between liability rules and property rules. Calabresi and Melamed, ${ }^{58}$ as well as Kaplow and Shavell,59 seem to draw the same conclusion regarding the doubtful equivalence of these two alternative forms of entitlement. Kaplow and Shavell conclude that possessory interests are best protected by property rights, while liability rules prevail in cases of harmful externalities. ${ }^{60}$ Demsetz provided that in markets with positive transaction costs, the initial allocation of the liability rule would in fact have an impact on resource allocation. ${ }^{61}$ Consequently, allocation of the rule of liability should take into account which party can avoid the costly interaction at the lowest cost. A normative interpretation of the Theorem indicates that legal rules minimising transaction costs are to be preferred as more effective. ${ }^{62}$

56 Calabresi, G., 'Transaction Costs, Resource Allocation and Liability Rules: A Comment', J Law Econ, Vol 54 (1968), pp. 13, pp. 49-70.

57 Demsetz, H., 'When Does the Rule of Liability Matter?' J Legal Studies, Vol 1 (1972), pp. 13-28.

58 Calabresi, G., and Melamed, A. Douglas, 'Property Rules, Liability Rules, and Inalienability: One View of the Cathedral', Harv L Rev, Vol 85 (April 1972), pp. 1089-128.

59 Kaplow, L., Shavell, S.M., 'Property Rules versus Liability Rules: An Economic Analysis', Harv L Rev, Vol 106 (1996), pp. 713-90.

60 Kaplow, Shavell (1996), pp. 723-54.

61 Demsetz, H., 'Toward a Theory of Property Rights', Am Econ Rev, Vol 57 (May 1972), pp. 347-59.

62 Polinsky, A.M., An Introduction to Law and Economics, Boston: Little Brown and Company (1989), pp. 25-45. 
Ayres and Talley developed their own normative interpretation of the Theorem, focusing on private information as transaction costs. ${ }^{63}$ Ayres and Talley consider that when two parties have private information about how much they value an entitlement, endowing each party with a partial claim to the entitlement can reduce the incentive to behave strategically during bargaining by inducing greater disclosure. ${ }^{64}$

\subsubsection{Fairness as Justice and Rawls}

\subsubsection{The Theory of Justice}

Equity and justice considerations have traditionally played an important role with regard to the structure and application of legal rules. Recently, justice and equity as objectives have been considered in relation to earlier stages of the law-making process, as for instance in the process of allocating scarce resources and addressing society's inequalities. Rawls' A Theory of Justice was a major contributor to the development of a model on equity applied in the field of institutional choices and changes. ${ }^{65}$

Rawls builds on the well-established theoretical framework of the social contract. ${ }^{66} \mathrm{He}$ considers that just, obligatory and stable principles for ordering the basic structure of society are more likely to be arrived at if the affected person views the process as an effort to reach agreement. Thus, each person is awarded an equal share in formulating principles and, by accepting the benefits of the agreements, assumes a duty to accept their obligations. According to Rawls, individuals gather under societal frameworks in order to promote their mutual advantage. Society should not limit its endeavours to advancing its members' benefits but should in general be 'regulated by a public conception of justice'. Members of a society should accept the 'fundamental principles of justice' and should also know that others accept the same principles. ${ }^{67}$

Rawls intended to take the Contractarian Theory a step further by considering not only forms of government, but also the basic principles

63 Ayres, I., Talley, E., 'Solomonic Bargaining: Dividing a Legal Entitlement

to Facilitate Coasean Trade', Yale LJ, Vol 104 (1995), pp. 1027-1117.

64 Ayres, I., Talley, E. (1995), pp. 1027-1117.

65 Rawls (1972).

66 On natural law and justice see Weinreb, L., Natural Law and Justice, Cambridge, MA: Harvard University Press (1987), pp. 224-67.

67 See also Christie, G.C., 'The Importance of Recognizing the Underlying Assumptions of Legal and Moral Arguments: Of Law and Rawls', Australian J Legal Philosophy, Vol 28 (2003), pp. 39-52. 
that will rule on these forms. Although Rawls himself did not attempt to apply his model to private relations, the proponents of his theory did. 68 The classical social contract theory presupposes the achievement of consensus between individuals in a society. ${ }^{69}$ Rawls contributed by developing the preconditions and negotiating the environment for such a consensus. ${ }^{70} \mathrm{He}$ assumes that individuals are gifted both with rationality and intuition, and are able to select the option that better furthers their objectives. Individuals' rational reflection will thus lead them to understand the desirability of ranking principles, in order to later maximise their collective preferences.

Individuals participating in this fundamental bargaining process are to be found in the 'original position'. They are to act without envy, in order to maximise social goods without being influenced by destructive motives and feelings. In order to guarantee the absence of envy, Rawls limits the individuals' knowledge of their own situation. ${ }^{71}$ In the original position, participants have their common sense, self-interest and knowledge of each of the general facts about human nature and society. ${ }^{72}$ Nevertheless, as no one knows if he/she is poor or rich, black or white, male or female, strong or weak, sick or healthy, or any other particular facts regarding their own circumstances, actors are bargaining 'under a veil of ignorance'. Rawls considers that inherited or acquired characteristics, such as wealth, intelligence and strength, should not be relevant in this initial bargaining position. He assumes that people are incapable of envy and that they have no mutual interest in each other. ${ }^{73}$ Finally, Rawls

68 A classic example of an attempt to broaden the Rawlsian model is that of Swygert and Yanes, who applied Rawls to private contractual relations.

69 For the relation between Kant's contract theory and Rawls', see Ripstein, A., 'Private Order and Public Justice: Kant and Rawls', University of Toronto, Legal Studies Research Paper No. 894431 (2006).

70 See also, Mikhail, J., 'Rawls' Linguistic Analogy: A Study of the Generative Grammar Model of Moral Theory Described by John Rawls in "A Theory of Justice"' (PhD Dissertation, Cornell University, 2000), Georgetown Public Law Research Paper No 766464 (1 May 2000), discussing the issue of moral institutions on the basis of a linguistics approach.

71 People are usually influenced by their own situation and seek to gain as much as possible, a situation that disfavors any consensus. Rawls (1972).

72 See also Apreda, R., 'Underlying Counterfactual Conditionals in Rawls' "Justice as Fairness" - How the Overlapping Consensus Becomes Functional to the Original Position', Universidad del CEMA Documento de Trabajo No 238 (June 2003), pp. 1-19.

73 Rawls (1972), p. 144. 
presupposes that there are some 'primary goods, including wealth, liberty and power, which rational men would certainly desire' ${ }^{74}$

Obviously, the 'initial bargaining position' is a metaphorical situation aimed at reflecting principles of neutrality and impartiality. These theoretical assumptions are certainly not new phenomena and are also found in the works of Locke and Kant. ${ }^{75}$ Rawls continues with the crystallisation of two fundamental principles ruling his model: those of equal liberty and distributive justice. ${ }^{76}$ Equal liberty covers the freedom of conscience, liberty of the person, political rights, speech, assembly and association.

Rawls builds upon the principle of efficiency. When goods are distributed and individuals are no longer willing to trade goods they have received for goods held by others, the distribution is efficient. Rawls clarifies that the principle of efficiency cannot give any indication of whether the distribution is fair or not, but tries to explore whether the application of this second principle will lead to a distribution that is both efficient and just. Rawls is thus attempting to consider systems in which the operation of the principle of efficiency would produce a just distribution, having as a starting point the fact that 'the principle of efficiency cannot serve alone as a conception of justice' ${ }^{77}$

Rawls proceeds with a direct reference to the obligations and duties of individuals in society. He makes a distinction between moral duties and moral obligations. Moral duties include the duty of mutual respect and the duty to avoid causing unnecessary suffering. In line with the Rawlsian 'principle of fairness', individual obligations originate in the basic principle that an individual should not gain from the cooperative effort of others without contributing his or her fair share. ${ }^{78}$

74 Rawls (1972), p. 62.

75 Locke, J., 'Second Treatise on Civil Government: Essays by Locke, Hume, and Rousseau', in Baker, E. (ed.), Social Contract: Essays by Locke, Hume, and Rousseau, New York: Oxford University Press (1962), pp. 3-143. With regards to the work of Kant see Murphy, G.J., 'Hume and Kant on the Social Contract', Philosophical Studies, Vol 33 (1978), pp. 65-79.

76 Rawls (1972), pp. 11, 60. See also Locke, J., 'Of Property', in May, L., Brown, L. (eds), Philosophy of Law, Oxford: Wiley-Blackwell (2009), pp. 251-8. According to the priority principle, liberty in Rawls' work is the first principle to be satisfied. Thus, justice cannot be applied before liberty is.

77 Rawls (1972), p. 71.

78 This is the principle of reciprocity or mutual benefit. 


\subsubsection{The international dimension of fairness}

Applying Rawls' Theory of Justice at the international level would have as an effect the equal distribution of primary social goods among individual members of a global society, unless unequal distribution would benefit the least favoured in this world. ${ }^{79}$ Nevertheless, Rawls did not support the extension of the scope of his original theory to also cover the regulation of international society, and proposed instead a nuanced moral theory, presented in his contribution on the Law of Peoples. ${ }^{80}$ Rawls rejects liberal imperialism in his consideration that such a principle imposes liberal standpoints on all peoples, treating those peoples instrumentally and without respect for their own way of honouring liberal ideals. ${ }^{81}$

In the theoretical framework of the Law of Peoples, the fictional forum of 'original position' exists, but the parties are no longer 'free and equal individuals'; rather, they are 'free and equal peoples'. ${ }^{82}$ Rational representatives of liberal peoples are being 'situated symmetrically' subject to a veil of ignorance that excludes knowledge of territorial size, population, strength of people, level of economic development or natural resources. ${ }^{83}$ Peoples in the 'Society of Peoples' would thus be able to agree upon the following principles of justice: freedom and independence of Peoples; observation of treaties and undertakings; the duty of non-intervention; the right to self-defence; the obligation to honour human rights; observation

79 Rawls, J., The Law of Peoples, Cambridge, MA: Harvard Univerity Press (2001), pp. 1-54.

80 With regard to a defence of Rawls' approach to international justice see Reidy, D., 'A Just Global Economy: In Defense of Rawls', J Ethics, Vol 11 (2007), pp. 193-236. For an interesting application of Rawls' theory to international environmental issues see Shelton, D., 'Describing the Elephant: International Justice and Environmental Law', in Ebbesson, J., Okowa, P. (eds), Environmental Law and Justice in Context, Cambridge: Cambridge University Press (2009), pp. 55-76. See also Twinning, W., 'Law, Justice and Rights: Some Implications of a Global Perspective', in Ebbesson, J., Okowa, P. (eds), Environmental Law and Justice in Context, Cambridge: Cambridge University Press (2009), pp. 76-115.

81 Among the many critiques of the application of Rawls' theory, one that stands out is Elkins, D. 'Responding to Rawls: Toward a Consistent and Supportable Theory of Distributive Justice', BYU J Public Law, Vol 21 (2007), pp. 267-323.

82 Rawls (2001), pp. 11-85.

83 Pettit, P.N., 'Rawls' Peoples' in Martin, R., Reidy, D. (eds), Envisioning a New International Order - Essays on Rawls' Law of Peoples, Oxford: Blackwell (2005), pp. 38-55. 
of restrictions in the conduct of war; and assistance to peoples living under unfavourable conditions.

Rawls' choice to focus on 'peoples' as major players rather than 'states' is motivated by the will to avoid being attached to the traditional idea of sovereignty. Rawls presents five different types of domestic societies:84 'reasonable liberal peoples', 'decent peoples', 'outlaw states', 'societies burdened by unfavourable conditions' and 'benevolent absolutism'. According to Rawls, only the first two categories qualify for respect and tolerance (and thus interaction with other peoples) in order to agree upon the creation of rules of cooperation. In his international view of fairness, the liberal and decent peoples agree on the design and functioning of a global institutional order, based on the rules of good conduct, obedience and cooperation. Rawls regards liberal democratic peoples as corporate moral agents, as persons in the moral sense of the term. The fact that representatives of equal peoples and not persons determine the content of the Law of Peoples brings Rawls' theory into contrast with the dominant cosmopolitan standard of global justice. According to cosmopolitan critique, Rawls treats individual persons unequally. ${ }^{85}$

Rawls claims that parties have a 'duty of assistance' in his international justice theory, but he fails to justify this claim satisfactorily because, given the size of omission and indifference of developed countries to assist developing countries, this would actually classify developed countries as 'outlaw states' under the Rawlsean theory of the peoples. ${ }^{86}$ In fact, such outlaw states are denied equal respect and tolerance and thus are not accepted as equal partners in the elaboration of international rules.

Rawls presents two major general requirements for global or international economic relations. ${ }^{87}$ According to the first principle, wellordered peoples are obligated, as a matter of justice, to take affirmative steps to aid those burdened societies unable to constitute and sustain themselves as well-ordered peoples. According to the second, trade and economic relations between well-ordered peoples are to be free and fair, and therefore mutually advantageous for all well-ordered peoples over the long term. These two principles are the major objectives that the international community must meet in terms of justice. It deserves to be noted that the principle of free and fair trade entails a commitment to

\footnotetext{
84 Rawls (2001), pp. 113-21.

85 See Beitz, C.R., 'Rawls's Law of Peoples', Ethics, Vol 110 (2000), pp. 669-96.

86 Rawls (2001), pp. 105-13.

87 Rawls (2001), pp. 113-21.
} 
transactional justice without, however, requiring the limitation of international economic inequalities.

According to Rawls, apart from these two fundamental obligations, peoples may take on additional obligations by means of treaty making or customary practice.

The duty of assistance is the well-ordered peoples' obligation to assist burdened societies to become well-ordered peoples. The characterisation 'well-ordered' does not, however, presuppose 'liberal and democratic people' ${ }^{88}$ Well-ordered people cannot be too poor; thus, material wealth is considered sufficient to sustain the rule of law and a stable government. ${ }^{89}$ Wealthy states are under the obligation to discharge the duty of assistance prior to committing to national projects or any other obligations. Thus, well-ordered peoples that do not satisfy their duty of assistance are in violation of the first principle of international justice. However, Rawls fails to address the moral implications of this violation.

Rawls states that well-ordered peoples are to refrain from monopolising markets, forming cartels and acting as oligopolies, or in any other way bringing any frustration to free and fair international or global trade and economic relations. Furthermore, trade with or between 'burdened peoples' will likely involve unequal bargaining positions.

\subsubsection{A Dualistic Approach}

While Rawls' theory has attempted to explain the regulation of the relationship between individuals and the state, or among peoples and international justice, the Coase Theorem focuses on the regulation of relationships between individuals. Where regulation of individuals is needed, it should be formulated on the basis of the result that free bargaining of the parties would attain in a market with no transaction costs. ${ }^{90}$

88 It requires, however, that peoples are decent, in that they are organised through a genuine scheme of social cooperation between members as persons or moral agents.

89 In this respect, Rawls emphasises that wealth does not guarantee a well-ordered society.

90 See Tuori, K., Critical Legal Positivism, Aldershot: Ashgate (2002), pp. 154-99 and Swygert, M.I., Yanes, K.E., 'A Unified Theory of Justice: The Integration of Fairness into Efficiency', Washington L Rev, Vol 73 (1998), pp. 249-327, available at SSRN: http://ssrn.com/abstract=81948. For a critique of Swygert and Yanes' approach, see Korobkin R.B., Ulen T.S., 'Efficiency and Equity: What Can Be Gained by Combining Coase and Rawls?', Washington L Rev, Vol 73 (1998), pp. 329-49. 
Obviously, there are no explicit equity considerations in the Theorem. However, integration of such a perspective is not incompatible with the spirit of the Coasean model. Coase himself has underlined the importance of governmental interference in cases where the market does not fulfil the Theorem's assumptions. Though the Coasean model guarantees the efficiency output for transactions, it has in some cases been deemed inappropriate, especially where parties present a considerable disparity in bargaining power. Thus, in general, the regulation of such transactions may not be based on the agreement those parties would have reached in the absence of transaction costs. ${ }^{91}$

In this respect, intervention by means of governmental regulation would not aim at the restitution of the transaction's efficiency, but more at safeguarding of its equity. Legal restrictions to freedom of contract are introduced to remedy the inequity in the parties' bargaining power that would inevitably lead to inequitable assignment of the wealth output. In cases where there is a considerable disparity of bargaining power between the parties, no real negotiation can take place, let alone a Coasean negotiation. ${ }^{92}$

Though the Law of Peoples is interesting and the principles presented in it could partly be applied to the protection of TKGR, it is mainly Rawls' Theory of Justice and the methodological framework it introduces that will be employed in this book. The Rawlsian 'veil of ignorance', 93 under which the parties will have to negotiate, could change the conditions under which Coasean negotiations take place, integrating an equity perspective into the efficiency analysis. One of the problematic issues arising when discussing TKGR protection is the fact that TKGR rightholders award TKGR a greater value than appropriate, expecting to remedy North/South inequality by means of TKGR protection, proceeding to an evaluation of the fairness aspect of an otherwise efficient entitlement. Such an attempt to employ the 'veil of ignorance' changes the prerequisites under which the Theorem will apply, since the parties are fully informed about the costs and benefits of the transaction but are

91 For an interesting combination of the objectives of efficiency and equity, see Mattei, U., Comparative Law and Economics, Ann Arbor: University of Michigan Press (1997), pp. 13-25.

92 See in this respect Kessler, F., 'Contracts of Adhesion: Some Thoughts about Freedom of Contract', Columbia L Rev, Vol 43 (1943), pp. 629-42, stating that where there is a disparity of bargaining power there is no real negotiation. It is the stronger party that is dictating the terms and conditions of the agreement; the weaker party has a 'take it or leave it' choice.

93 Rawls (1972), pp. 102-5. 
unaware of which party to the agreement they will represent. In this model, providing for the hidden identities of the parties, the veil of ignorance will guarantee a level of equity and fairness at the core of the system. ${ }^{94}$ On the whole, this dualistic approach is in line with the two fundamental objectives of the CBD: the importance of 'sustainable use' of TKGR while guaranteeing 'fair and equitable sharing' of the benefits arising thereof. This combined model may thus be applied to evaluate the alternative forms of protection and regulation of TKGR exploitation.

94 Distributive arrangements. 